\title{
The Accurate and Inaccurate Conceptions Acquired by Society Throughout the COVID-19 Pandemic
}

\section{COVID-19 Pandemi Sürecinde Toplumda Doğru ve Yanlış Bilinenler}

\author{
Yasemin Durduran ${ }^{1}$, Lutfi Saltuk Demir ${ }^{1}$, Mehmet Uyar ${ }^{1}$, Hasan Kucukkendirci ${ }^{1}$, Gullu Eren ${ }^{1}$, \\ Tahir Kemal Sahin ${ }^{1}$
}

${ }^{1}$ Necmettin Erbakan University, Meram Faculty of Medicine, Department of Public Health, Konya, Turkey

Address correspondence to: Gullu Eren, Necmettin Erbakan University, Meram Faculty of Medicine, Department of Public Health, Konya, Turkey

e-mail: gulludogru7@gmail.com

Gelis Tarihi/Received: 1 December 2021 Kabul Tarihi/Accepted: 11 March 2021

\begin{abstract}
$\ddot{O} z$
Amaç: Bu çalışmada; bir halk sağlığı problemi olarak ele alınan ve bulaş riski yüksek olan COVID-19 hastalığına ilişkin doğru ve yanlış bilinenleri tespit etmek amaçlanmıştır.

Gereçler ve Yöntem: Çalışma https://docs.google.com/forms adresinden online olarak Mayıs 2020 tarihinde gerçekleştirildi. Anket formu, sosyodemografik özellikler ve COVID-19 ile ilgili 40 sorudan oluşmaktadır. Çalışma sonrasında anket sorularına verilen cevaplar SPPS veri programına giriş yapılarak analiz edildi.

Bulgular: Araştırmaya katılan 580 kişinin 363'ü $(\%$ 62,6) kadındı. Katılımcıların ortanca yaşı 34,0 (18,0$77,0)$ idi. Anketi dolduranların 342 'si $(\% 59,0)$ evli, 438 'i $(\% 75,5)$ üniversite ve yüksek lisans mezunu idi. Araştırmaya dahil edilen bireylerin 497 'si $(\% 85,6)$ COVID-19 hakkında bilgi sahibi olmak için televizyon/ haber kanallarını izlediklerini belirttiler. COVID-19 ile ilgili soruların çoğu katılımcılar tarafından doğru cevaplandı. En çok doğru yanıtlanan önerme oranı \% 99,5 (577), en az doğru yanıtlanan önerme oranı \%23,6 (137) idi. Önermelere verilen doğru yanıtlar açısından cinsiyetler arasında istatistiksel olarak anlamlı bir fark bulundu $(p<0.05)$

Sonuç: Katılımcıların büyük çoğunluğunun COVID-19 ile ilgili en az bir haber kaynağından yararlandığı belirlendi. Katılımcılar genellikle COVID-19 hakkında doğru bilgiye sahipti. Çoğunlukla yanlış bilinen konular hakkında toplumun farkındalığını artırmak için eğitim programları planlanabilir.

Anahtar Kelimeler: COVID-19, maske, el yıkama, doğru/yanlış kavramlar Abstract

Aim: In this study, it was aimed to identify the accurate and inaccurate conceptions among the society on COVID-19 disease, which is considered as a public health problem and has a high risk of transmission. Materials and Methods: The research was performed online at https://docs.google.com/forms in May 2020. The questionnaire form was composed of 40 queries, which were on sociodemographic characteristics and COVID-19. Following the study, the answers obtained from the questionnaire were analyzed by inserting related data to the software of SPSS

Results: Of 580 participants involved in the study, $363(62.6 \%)$ were female. The median age of the participants was $34.0(18.0-77.0)$. Of the individuals who completed the questionnaire, $342(59.0 \%)$ were married and $438(75.5 \%)$ were university graduated and / or postgraduated. Of the individuals included in the study, $497(85.6 \%)$ stated that they watched television / news channels to be informed about COVID-19. Most of the questions related to COVID-19 were answered accurately by the participants. The percentage of the premise, which was answered most accurately, was $577(99.5 \%)$, whereas the lowest percentage of the accurately answered premise was $137(23.6 \%)$. It was found that there was a statistically significant difference among the genders in terms of the percentage of accurate responses to the conceptions $(p<0.05)$.

Conclusion: It was determined that the vast majority of the participants utilized from at least one news resource on COVID-19. Participants typically have accurate knowledge about COVID-19. Educational programs can be planned to enhance the awareness of the society about the conceptions, which were answered mostly inaccurately.
\end{abstract}

Key words: COVID-19, face mask, hand hygiene, accurate/inaccurate conceptions

Cite this article as: Durduran $Y$, Demir LS, Uyar M, Kucukkendirci H, Eren G, Sahin TK. The Accurate and Inaccurate Conceptions Acquired by Society Throughout the COVID-19 Pandemic. Selcuk Med J 2021;37(3): 200-208
Disclosure: None of the authors has a financial interest in any of the products, devices, or drugs mentioned in this article. The research was not sponsored by an outside organization. All authors have agreed to allow full access to the primary data and to allow the journal to review the data if requested. 


\section{INTRODUCTION}

Coronavirus disease 2019 (COVID-19) was first reported on December 31, 2019, as a pneumonia case, which had an epidemiologic association with the seafood market in Wuhan, China, and in January 2020 , a novel strain of coronavirus was identified as the cause of these pneumonia cases (1). COVID-19, which is rapidly spreading due to globalization and international travel, was declared as a pandemic by the World Health Organization (WHO) on March 11, 2020 , and on the same date, the disease was also detected officially in Turkey (2). Until now, a total of 63.697.277 cases and 1.476.521 deaths have been reported across the world (3). The most common symptoms of the disease are fever, dry cough, and shortness of breath. Myalgia, expectoration, diarrhea, and sore throat are among less prevalent symptoms (4). Mild symptoms are observed in most of the cases, whereas in some cases pneumonia and multiple organ failure have been detected (2).

It is considered that two main modes of transmission for severe acute respiratory syndrome coronavirus 2 (SARS-CoV-2), which is the culprit virus of COVID-19, are respiratory droplets and contact with infected hosts (5). Droplet conduction occurs through large respiratory particles, which are exposed to gravitational forces, and are usually larger than the volume of $5 \mu \mathrm{m}$. These droplets have the tendency of not moving away more than 1 meter. Thus, a 2-metered distancing is crucial not to contact with the potentially infected hosts. When anyone who has been infected with SARS-CoV-2 coughs or exhales, he/she generates infective respiratory droplets that might be inhaled by anybody else who is at a close distance to them. Moreover, droplets, which spread to nearby surfaces, might be an origin of transmission for the nose, mouth, and eyes via the hands. Likewise, other human corona viruses, SARS-CoV-2 can also live on surfaces for 4-72 hours, depending on the features of the surface (5-7). WHO verified in its situation report, which was published on 19 February, that the average duration for incubation was 4-5 days, but it could extend up to 14 days (8). It is not known precisely how long an individual could be contagious for COVID-19. The increase in the amount of viral-RNA, which were detected in the samples at the onset of the disease, manifests that the initial days of the disease are risky in terms of being contagious (9). More evidence is required to clarify the issues on whether the disease yields an immune response or how long it will last, even if it has a protective impact
(10).

Upon considering the epidemic of COVID-19 pandemic, there is no vaccine available for this deadly virus for the time being. Therefore, the most efficient way of preventing the disease is not to be exposed to the virus. Nowadays, infection control measures such as hand hygiene and the usage of personal protective equipment (PPE) are recommended to prevent the contagion $(11,12)$. WHO recently has published a guideline on COVID-19 related to water, sanitation, hygiene, and waste management, and underscored the significance of practicing these measures in the healthcare settings. The guideline promotes having frequent and proper hand hygiene as one of the most essential measures to prevent being infected with SARS-CoV-2 and highlights the regular cleaning and disinfection practices as well as the safe management of health waste and feces (5). Several measures have been taken in our country to slow the spread of the virus and maintained to be taken. Maintaining social distance, wearing face masks, washing hands, keeping social isolation come to the forefront as the essential measures $(13,14)$. It was stated in the public mandate, which was announced by the Ministry of Interior, that "Our citizens and employees must wear face masks to enter the workplaces, markets and public workplaces of the provinces and districts. The requirement to wear a face mask will also take effect for vendors working in the marketplaces."Furthermore, it is necessary to know what the accurate practices in various circumstances are, such as the issues required to be paid attention while breastfeeding the baby and using the public transportation. To illustrate, based on the current scientific data, if there is a potentiality of having contact or being infected with the COVID-19 then it is recommended that the mother should keep breastfeeding or nurturing the baby through milking by adhering to the guidelines such as wearing a face mask, and ensuring the necessary hygiene rules (15). Medical masks, which are the most used equipment, are the type of mask that individuals should use under normal circumstances (16).

To perform the rest of the process efficiently, it is considered vital to analyze the accurate and inaccurate conceptions of society and the perception of the public related to this issue, though the issue of accurate and inaccurate conceptions are on the agenda (17) of staff in the field of public health care and efficient preventive approaches are suggested by them (18). Hence, this research has been designed to identify the accurate and inaccurate conceptions 
related to the novel coronavirus and to perform educational trainings for the misconceptions.

\section{MATERIALS AND METHODS}

This cross-sectional study was available online at 'https://docs.google.com/forms' between May 13 and May 20, 2020 and was conducted through the access of 580 participants to the survey form, which was available online via the internet. The questionnaire form, which was generated by the researchers through reviewing the literature, is comprised of two different sections. The first section involves sociodemographic characteristics, while the second section contains general queries, which are supposed to be well-known by every individual, related to social isolation, social distancing, usage of PPE such as face mask, washing hands properly, and hygiene practices throughout the pandemic. The first section consists of 8 queries and the second section consists of 32 queries. Survey questions measuring information about COVID-19 had two options, true
Table 1. Sociodemographic characteristics of participants

\begin{tabular}{lll}
\hline Variables (n: 580) & $\mathbf{n}$ & $\%$ \\
\hline Gender & 363 & 62.6 \\
$\quad$ Female & 217 & 37.4 \\
$\quad$ Male & & \\
Marital Status & 342 & 59.0 \\
$\quad$ Married & 215 & 37.1 \\
$\quad$ Single & 23 & 3.9 \\
$\quad$ Widow/Widower & & \\
Type of family & 535 & 92.2 \\
$\quad$ Nuclear family & 45 & 7.8 \\
$\quad$ Extended family & & \\
Educational Status & 18 & 3.1 \\
$\quad$ Primary school graduated & 19 & 3.3 \\
$\quad$ Secondary school graduated & 105 & 18.1 \\
$\quad$ High school graduated & 334 & 57.6 \\
$\quad$ University graduated & 104 & 17.9 \\
Postgraduated & & \\
Occupation & 63 & 10.9 \\
$\quad$ Housewife & 154 & 26.6 \\
$\quad$ Civil servant & 122 & 21.0 \\
Student & 38 & 6.6 \\
Laborer & 87 & 15.0 \\
Health care staff & 116 & 19.9 \\
Others & & \\
Presence of chronic disease & 117 & 20.2 \\
$\quad$ Yes & 463 & 79.8 \\
$\quad$ No & & \\
\hline
\end{tabular}

Table 2. Knowledge levels of participants on COVID-19 (accurate conceptions)

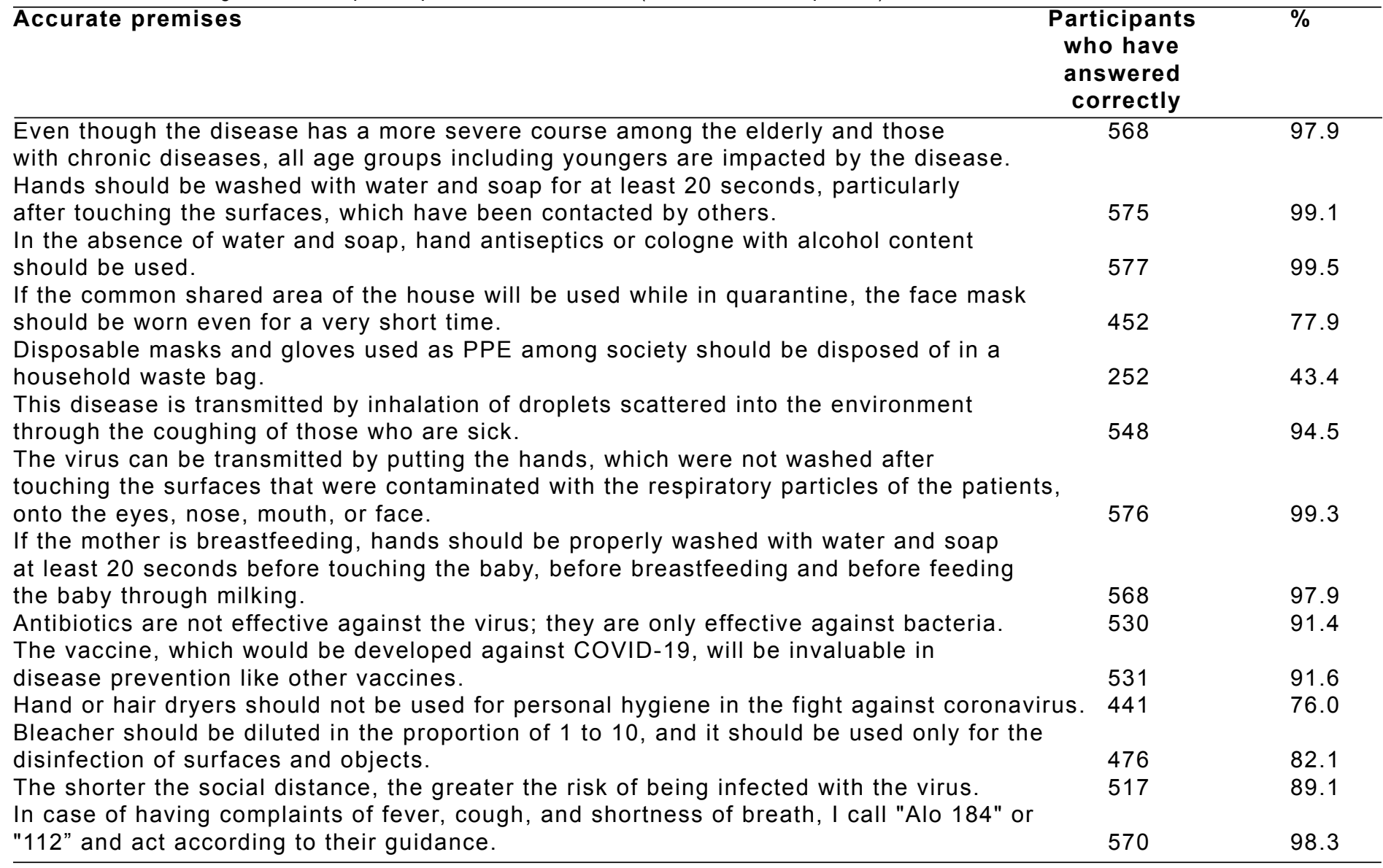


Table 3. Knowledge Levels of Participants on COVID-19 (inaccurate conceptions)

\begin{tabular}{|c|c|c|}
\hline Inaccurate premises & $\begin{array}{l}\text { Darticipants } \\
\text { answered } \\
\text { prrectly n }\end{array}$ & $\%$ \\
\hline $\begin{array}{l}\text { It is adequate to wash textiles such as clothes and towels with normal } \\
\text { detergent at } 30^{\circ} \mathrm{C} \text {. }\end{array}$ & 410 & 70.7 \\
\hline Everyone must wear an N95 mask to protect against the virus. & 429 & 74.0 \\
\hline $\begin{array}{l}\text { If the visor is to be used, there is no need to use a surgical mask. } \\
\text { If there is no handkerchief during coughing or sneezing, one should sneeze/cough }\end{array}$ & 492 & 84.8 \\
\hline at the shoulder, which is part of the arm covered with clothes. & 137 & 23.6 \\
\hline Gloves must be used when leaving the house. & 325 & 56.0 \\
\hline There is no harm in touching the front of the face mask while using and doffing it. & 551 & 95.0 \\
\hline Using vinegar is useful in protecting from this infection. & 352 & 60.7 \\
\hline $\begin{array}{l}\text { It is beneficial to wash the nose with saltwater to provide hygiene in protecting } \\
\text { against COVID-19. }\end{array}$ & 388 & 66.9 \\
\hline $\begin{array}{l}\text { If public transportation is being used during the pandemic, it would be adequate in } \\
\text { terms of protection measures that no one is standing in the vehicle. }\end{array}$ & 522 & 90.0 \\
\hline $\begin{array}{l}\text { The virus cannot be transmitted in a region where there is a hot and humid climate. } \\
\text { It is enough to wear a black-colored face mask in places such as the }\end{array}$ & 538 & 92.8 \\
\hline marketplace and market. & 532 & 91.7 \\
\hline $\begin{array}{l}\text { It is not necessary to wear a mask if there are few people in public transportation. } \\
\text { It is inappropriate for a female who has recently given birth to an infant and has }\end{array}$ & 568 & 97.9 \\
\hline been infected with coronavirus to breastfeed her baby. & 304 & 52.4 \\
\hline $\begin{array}{l}\text { It is not required to break family and friend gatherings during these days of a global outbreak. } \\
\text { The one who has worn a medical mask can be in close contact with people without }\end{array}$ & 532 & 91.7 \\
\hline paying attention to the social distancing. & 567 & 97.8 \\
\hline Herbs such as garlic and turmeric should be consumed by everyone during the pandemic. & 398 & 68.6 \\
\hline There is a robust treatment method specific to COVID-19 infection. & 471 & 81.2 \\
\hline
\end{tabular}

and false. What is meant by what is known correctly in the study is the correct knowledge of the protective practices in the COVID-19 pandemic period by the respondents. What is described as incorrect is the fact that the participants know the correct statements for the disease and preventive measures. Local ethics committee approval (Decision number: 2020/2477) was obtained following the approval of the Ministry of Health, which was performed via applying to the link of "https://bilimselarastirma.saglik.gov.tr". To be at the age of 18 and over and being a volunteer to participate in the research were inclusion criteria of the study. To eliminate the possibility of missed opportunities, it is kindly requested from the participants at the end of the questionnaire to write their e-mail addresses and hence they could be informed later on. Notifications were sent to the participants who had completed the questionnaire and shared their e-mail addresses when the questionnaire was closed to answer. Statistical analysis of data was conducted using the SPSS 24.0 statistical software package (IBM SPSS, Chicago, IL, USA). The median (minimum-maximum) values of numerical data, and number $(\mathrm{n})$ and percentage (\%) distributions were used to summarize categorical data. The chi-square $(x 2)$ test was performed to manifest the association between categorical variables. Statistical significance was considered as $p<0,05$.

\section{RESULTS}

The median age of the 580 participants who were involved in the study was $34,0(18,0-77,0)$ years. Of the individuals who completed the questionnaire, $363(62.6 \%)$ were female, while $342(59.0 \%)$ were married, and $438(75.5 \%)$ were university graduated and postgraduated. Among these, civil servants ranked first with a percentage of 154 (26.6\%), and it was followed by students with a percentage of 122 (21.0\%). Of the participants, $117(20.2 \%)$ had at least one chronic illness that required regular medication (Table 1).

Among the participants, 497 (85.6\%) stated that they watched television to be aware of COVID-19 and did not miss the latest news.Several premises about COVID-19 were directed to the individuals who participated in the study and asked if the answer was true or false. The conception that "alcoholcontaining hand antiseptic or cologne should be used in the absence of water and soap" was answered correctly by the participants with a proportion of 577 $(99.5 \%)$ and it was determined that this premise has 
Table 4. Comparison of the conceptions suggested for COVID-19 by gender

\begin{tabular}{|c|c|c|c|}
\hline & Gende & & $x^{2}$ value \\
\hline & $\begin{array}{l}\text { Female } \\
\text { n }(\%)\end{array}$ & $\begin{array}{l}\text { Male } \\
\text { n (\%) }\end{array}$ & \\
\hline $\begin{array}{l}\mathrm{t} \text { is adequat } \\
\text { hormal deter }\end{array}$ & & & \\
\hline Correct & $89(24.5 \%)$ & 81 (37.3\%) & 10.755 \\
\hline Incorrect & $274(75.5 \%)$ & $136(62.7 \%)$ & 0.001 \\
\hline Everyone mu & & & \\
\hline Correct & $108(29.8 \%)$ & $43(19.8 \%)$ & 6.963 \\
\hline Incorrect & $255(70.2 \%)$ & $174(80.2 \%)$ & 0.008 \\
\hline $\begin{array}{l}\text { f the commo } \\
\text { quarantine, } t\end{array}$ & & & \\
\hline Correct & $270(74.4 \%)$ & $182(83.9 \%)$ & 7.113 \\
\hline Incorrect & $93(25.6 \%)$ & $35(16.1 \%)$ & 0.008 \\
\hline $\begin{array}{l}f \text { there is no } \\
\text { sneeze/coug } \\
\text { clothes }\end{array}$ & & & \\
\hline Correct & $287(79.1 \%)$ & $156(71.9 \%)$ & 3.874 \\
\hline Incorrect & $76(20.9 \%)$ & $61(28.1 \%)$ & 0.049 \\
\hline Gloves must & & & \\
\hline Correct & $183(50.4 \%)$ & 72 (33.2\%) & 16.373 \\
\hline Incorrect & $180(49.6 \%)$ & $145(66.8 \%)$ & 0.000 \\
\hline $\begin{array}{l}\text { f the mother } \\
\text { with water an } \\
\text { pefore breas }\end{array}$ & & & \\
\hline Correct & $360(99.2 \%)$ & $208(95.9 \%)$ & 7.393 \\
\hline Incorrect & $3(0.8 \%)$ & $9(4.1 \%)$ & 0.012 \\
\hline $\begin{array}{l}\text { The virus car } \\
\text { and humid cl }\end{array}$ & & & \\
\hline Correct & $34(9.4 \%)$ & $8(3.7 \%)$ & 6.523 \\
\hline Incorrect & $329(90.6 \%)$ & $209(96.3 \%)$ & 0.011 \\
\hline
\end{tabular}

*: Only comparisons with $p<0.05$ are given in the table.

Table 5. Comparison of the conceptions suggested for COVID-19 by marital status

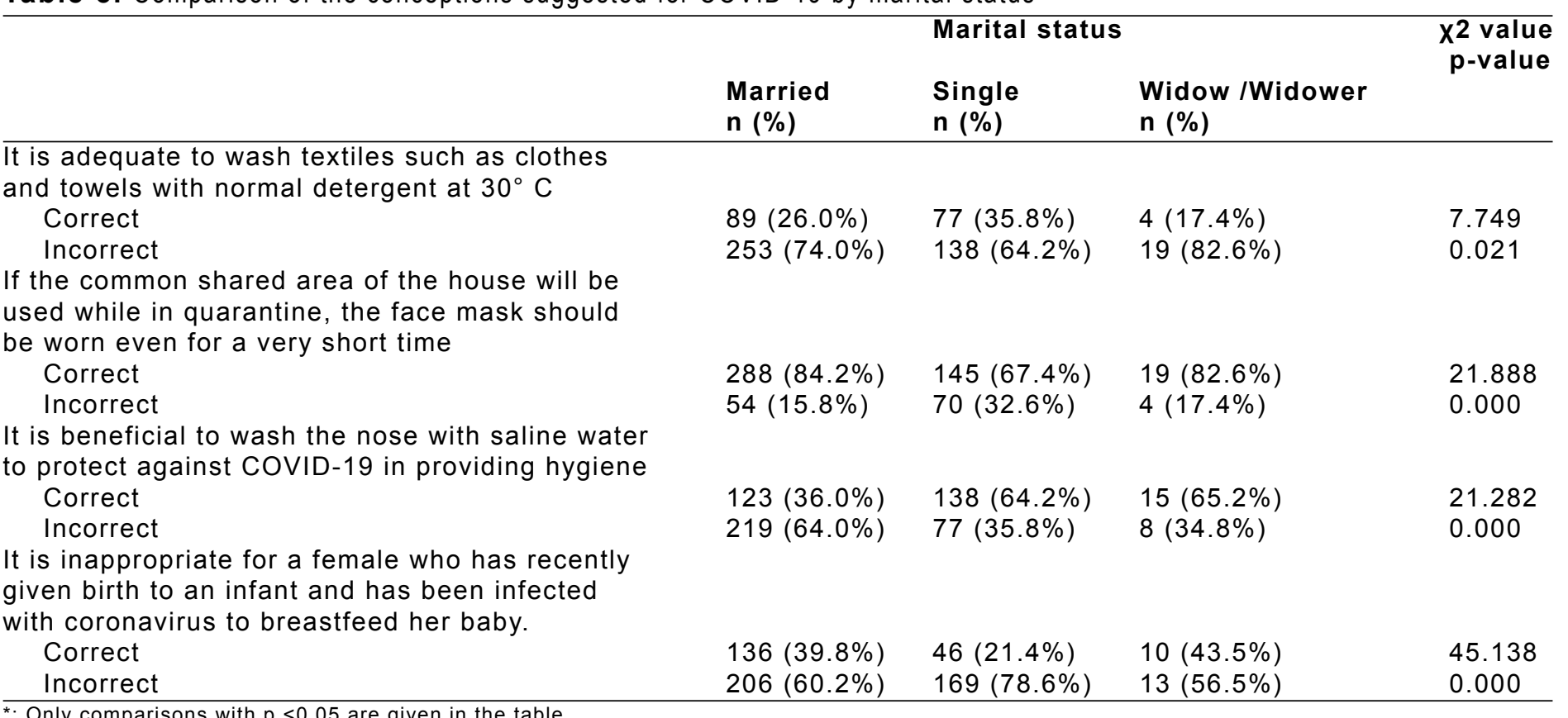


Table 6. Comparison of the conceptions suggested for COVID-19 by educational status

$\begin{array}{lllr}\text { Pre high } & \text { High } & \text { Post } & \text { X2 value } \\ \text { school } & \text { school } & \text { high } & \text { p-value } \\ \text { graduated } & \text { graduated } \\ \text { n (\%) } n(\%) & \text { graduated } & \end{array}$

It is adequate to wash textiles such as clothes and

n (\%) n (\%) n (\%)

towels with normal detergent at $30^{\circ} \mathrm{C}$

Correct

Incorrect

$\begin{array}{llll}6(16.2 \%) & 43(41.0 \%) & 121(27.6 \%) & 10.530 \\ 31(83.8 \%) & 62(59.0 \%) & 317(72.4 \%) & 0.005 \\ & & & \\ 21(56.8 \%) & 39(37.1 \%) & 91(20.8 \%) & 31.153 \\ 16(43.2 \%) & 66(62.9 \%) & 347(79.2 \%) & 0.000\end{array}$

Everyone must wear an $\mathrm{N} 95$ mask to protect against the virus Correct Incorrect

$16(43.2 \%)$

$66(62.9 \%)$

$347(79.2 \%)$

0.000

If the common shared area of the house will be used

while in quarantine, the face mask should be worn even

for a very short time

Correct

Incorrect

If the visor is to be used, there is no need to use a

surgical mask.

Correct

Incorrect

Disposable masks and gloves used as PPE among

society should be disposed of in a household waste bag.

Correct

Incorrect

Gloves must be used when leaving the house

Correct

Incorrect

It's okay to touch the front of the mask while using or

removing it.

Correct

Incorrect

Using vinegar is useful in protecting from this infection.

Correct

Incorrect

If public transportation is being used during the pandemic,

$23(62.2 \%)$

$14(37.8 \%)$

$79(75.2 \%)$

$26(24.8 \%)$

$350(79.9 \%)$

$88(20.1 \%)$

6.788

0.034

$12(32.4 \%)$

$25(67.6 \%)$

$23(21.9 \%)$

$82(78.1 \%)$

$53(12.1 \%)$

$385(87.9 \%)$

15.474

0.000

$29(78.4 \%)$

$8(21.6 \%)$

$48(45.7 \%)$

$175(40.0 \%)$

20.769

$57(54.3 \%)$

$263(60.0 \%)$

0.000

$27(73.0 \%)$

$66(62.9 \%)$

$162(37.0 \%)$

36.508

$10(27.0 \%)$

$39(37.1 \%)$

$276(63.0 \%)$

0.000

$4(10.8 \%)$

$33(89.2 \%)$

$9(8.6 \%)$

$96(91.4 \%)$

$23(62.2 \%)$

$42(40.0 \%)$

$63(60.0 \%)$

$16(3.7 \%)$

7.123

$422(96.3 \%)$

0.028

$14(37.8 \%)$

$163(37.2 \%)$

8.926

it would be adequate in terms of protection measures that

no one is standing in the vehicle.

Correct

Incorrect

The virus can not be transmitted in a region where there

is a hot and humid climate

Correct

Incorrect

It is enough to wear a black-colored face mask in places

such as the marketplace and market.

Correct

Incorrect

It is inappropriate for a female who has recently given

birth to an infant and has been infected with coronavirus

to breastfeed her baby.

Correct

Incorrect

Herbs such as garlic and turmeric should be consumed

by everyone during the pandemic.

Correct

Incorrect

The shorter the social distance, the greater the risk of

being infected with the virus.

Correct

Incorrect

*: Only comparisons with $p<0.05$ are given in the table.

\begin{tabular}{llll}
$10(27.0 \%)$ & $15(14.3 \%)$ & $33(7.5 \%)$ & 17.021 \\
$27(73.0 \%)$ & $90(85.7 \%)$ & $405(92.5 \%)$ & 0.000 \\
& & & \\
$10(27.0 \%)$ & $13(12.4 \%)$ & $19(4.3 \%)$ & 31.190 \\
$27(73.0 \%)$ & $92(87.6 \%)$ & $419(95.7 \%)$ & 0.000 \\
& & & \\
$7(18.9 \%)$ & $11(10.5 \%)$ & $30(6.8 \%)$ & 7.365 \\
$30(81.1 \%)$ & $94(89.5 \%)$ & $408(93.2 \%)$ & 0.025 \\
& & & \\
& & & \\
$6(16.2 \%)$ & $13(12.4 \%)$ & $29(6.6 \%)$ & 6.984 \\
$31(83.8 \%)$ & $92(87.6 \%)$ & $409(93.4 \%)$ & 0.030 \\
& & & \\
$19(51.4 \%)$ & $34(32.4 \%)$ & $129(29.5 \%)$ & 7.659 \\
$18(48.6 \%)$ & $71(67.6 \%)$ & $309(70.5 \%)$ & 0.022 \\
& & & \\
$24(64.9 \%)$ & $91(86.7 \%)$ & $402(91.8 \%)$ & 26.337 \\
$13(35.1 \%)$ & $14(13.3 \%)$ & $36(8.2 \%)$ & 0.000 \\
\hline
\end{tabular}


the highest percentage of being known correctly (Table 2). Whereas, the premise that "if there is no handkerchief during coughing or sneezing, one should sneeze/cough at the shoulder, which is part of the arm covered with clothes" was found to be the lowest known correct answer with proportion of 137 (23.6\%) (Table 3).

It was found that of the premises related to COVID-19, the percentage of knowing the inaccuracy of the premise that "it is adequate to wash textiles such as clothes and towels with normal detergent at $30^{\circ} \mathrm{C}$." and the percentage of knowing the accuracy of the premise that "if the mother is breastfeeding, hands should be properly washed with water and soap at least 20 seconds before touching the baby, before breastfeeding and before feeding the baby through milking." was significantly higher among females compared to males $(p<0.05)$. Besides, it was determined that the percentages for knowing the inaccuracy of the premises that "everyone must wear an N95 mask to protect against the virus.", "the virus can not be transmitted in a region where there is a hot and humid climate.", and the percentages for knowing the accuracy of the premise that "if the common shared area of the house will be used while in quarantine, the face mask should be worn even for a very short time." was significantly higher in males compared to females $(p<0.05)$. Furthermore, the inaccurate premise that "if there is no handkerchief during coughing or sneezing, one should sneeze/cough at the shoulder, which is part of the arm covered with clothes" was considered as an accurate knowledge by females predominantly (Table 4).

The cases of knowing the sentences about COVID-19 true or false in marital status groups are summarized in Table 5 . The educational status of the participants were categorized into 3 groups. The cases of knowing the COVID-19 sentences correctly or incorrectly in these groups are given in Table 6.

\section{DISCUSSION}

It was determined that the majority of participants were female, married, and have a higher level of education. It is an expected situation for the participants to have a high education level since a certain sociocultural level is required to accomplish the online questionnaire. The percentage of participants who received medication due to having a chronic disease is remarkable. This might be indicating that those with chronic diseases place more importance on the fight against the pandemic and so participate more frequently in the surveys.

The majority of individuals who participated in the study stated that they acquired the information about COVID-19 from communication resources such as television and social media. The fact that the COVID-19 pandemic has a wide coverage in the media, making special programs for pandemics every day on television channels, the announcement of the ban and regulations regarding the COVID-19 pandemic, particularly through television and social media, might have promoted the public awareness to obtain recent information and news about the outbreak by watching television.

It was observed that most of the participants were well-informed about the issues on the regulations and prohibitions regarding the COVID-19 pandemic, which are widely covered in the mass media. The premises such as, "even though the disease has a more severe course among the elderly and those with chronic diseases, all age groups including youngers are impacted by the disease.", "hands should be washed with water and soap for at least 20 seconds, particularly after touching the surfaces, which have been contacted by others.", and "in the absence of water and soap, hand antiseptics or cologne with alcohol content should be used." were to be known accurately by the majority of the participants. It was observed that the participants had a lower level of knowledge on some information, which was discussed among society without being investigated adequately and had not a scientific background.

"Textiles such as clothes, towels, sheets, which have been used by COVID-19 patients, should be washed with detergent at $60-90^{\circ} \mathrm{C} "(5,19)$. It was identified that $170(29.3 \%)$ of the participants had a misconception on this issue and there was a statistically significant difference between the two genders regarding this information. This difference might be since females have more accurate information on this issue. This variation might be resulting from the fact that there is a distinctive approach in Turkish society in terms of gender and females are more familiarized with the laundry than males.

Healthcare staff should use a medical mask when entering the wards, and the use of an N95 mask is required during the procedures such as tracheal aspiration and bronchoscopy, which lead to the generation of aerosols (16). Given this information, it was determined that $26.0 \%$ of the participants answered inaccurately to the premise that "everyone must wear an N95 mask to protect against the virus". 
Besides, it was found that males have more accurate information on this issue than females.

Disposable masks and gloves used as PPE among society should be disposed of in a household waste bag (13). The premise, which was directed to the participants based on this information, was known inaccurately by them with a proportion of $328(56.6 \%)$. The fact that this issue appears less frequently in the mass media compared to other issues might have averted the rise in the percentage of accurate awareness.

"Hands can quite easily mediate the transmission of the virus. When coughing and sneezing, it is necessary to cover the mouth with a handkerchief and throw the handkerchief into the trash, in cases where there is no handkerchief, it should be covered with the elbow" (20). About a quarter of the respondents answered this premise inaccurately, and it was determined that the related percentage for this inaccurate response was higher among females than males.

Wearing protective gloves is not an adequate measure to protect against the virus in open public spaces. Contact of hands with the face during the use of gloves may lead to being infected with the disease. Misperception of hygiene, which was arisen by the use of gloves in the person, might also lead to increased risky behaviors (20). Almost half of the individuals participating in the research know the premise given on this issue inaccurately. The conception of using gloves to prevent skin contact with the virus might have caused the accuracy percentage of information to be low.

There is no evidence that regular washing of the nose with saltwater, using vinegar, and consuming garlic protects against the virus of the COVID-19 outbreak $(20,21)$. It was observed that the participants had a relatively low proportion of accurate information about news that is unscientific, but popular in the mass media, such as usage of vinegar, consumption of herbs such as garlic, turmeric, and washing the nose with saltwater. It might be associated with the fact that modern non-medical views are stated frequently both by physicians and other people in our society through mass media.

Many scientific foundations underscore that breastfeeding is vital during the COVID-19 pandemic. The breastfeeding mother with COVID-19 (+) who is being treated at home should not be separated from her baby: WHO and many international scientific institutions recommend that breastfeeding should be continued by adhering to the hygiene rules (22-25).
It was determined that nearly half of the participants have misconceptions about this issue. Since this issue concerns mainly the nursing mothers and their parents, it may be the reason for the percentage of inaccurate information related to this issue.

\section{CONCLUSION}

As a result of this study, it was revealed that most of the individuals participating in the research had accurate information on COVID-19. Both accurate and inaccurate information, which takes place frequently in the mass media about COVID-19, is considered as correct by the participants. It has been detected that the accuracy and inaccuracy percentages of much information about the COVID-19 pandemic and protection from the pandemic vary among males and females. It is necessary to give only the accurate messages to the society, and it is necessary to avoid mentioning the inaccurate information even to correct misconceptions. These and similar studies are of great importance against the COVID-19 epidemic and infectious diseases that may threaten public health. The easiest, cheapest and safest method to protect public health is primary prevention such as hand hygiene and the use of a mask. Providing primary prevention is possible only if the public gets the right information and puts it into life.

The sample was not selected in the study, and a questionnaire was applied to those who can be reached by the researchers and who accept the study. Face-to-face interviews were not done sufficiently due to the pandemic and online questionnaires were filled out. The high level of education of most of the individuals who accepted to participate in the study is a limitation. So it doesn't generalize to the universe.

Conflict of interest: Authors declare that there is no conflict of interest between the authors of the article.

Financial conflict of interest: Authors declare that they did not receive any financial support in this study.

Address correspondence to: Gullu Eren, Necmettin Erbakan University, Meram Faculty of Medicine, Department of Public Health, Konya, Turkey

e-mail: gulludogru7@gmail.com

\section{REFERENCES}

1. Zhu N, Zhang D, Wang W, et al. A novel coronavirus from patients with pneumonia in China, 2019. N Engl J Med 2020;382:727-33.

2. World Health Organization [Internet]. WHO Director-General's opening remarks at the media briefing on COVID-19 - 
[cited 2020 Apr 10]. Available from: https://www.who.int/dg/ speeches/detail/who-director-general-s-opening-remarks-atthe-mission-briefing-on-COVID-19-11-march-2020.

3. Reported Cases and Deaths by Country, Terrtory or Conveyance. worldometers.info [İnternet]. [cited 2020 Dec 1]. Available from: https://www.worldometers.info/coronavirus/

4. Miri SM, Roozbeh F, Omranirad A, et al. Panic of buying toilet papers: A historical memory or a horrible truth? Systematic review of gastrointestinal manifestations of COVID-19. Hepat Mon 2020;20(3):1-4.

5. World Health Organization [Internet]. Water, sanitation, hygiene, and waste management for the COVID-19 virus: interim guidance - [cited $2020 \mathrm{Apr} 10$ ]. Available from: https:// apps.who.int/iris/handle/10665/331499

6. Kampf G, Todt D, Pfaender S, et al. Persistence of coronaviruses on inanimate surfaces and their inactivation with biocidal agents. J Hosp Infect 2020;104:246-51.

7. Van Doremalen N, Bushmaker T, Morris DH, et al. Aerosol and surface stability of SARS-CoV-2 as compared with SARS-CoV-1. N Engl J Med 2020;382(16):1564-7.

8. World Health Organization [Internet]. Coronavirus diease (COVID-19) situation reports 2020 - [cited 2020 May 10]. Available from: [https://www.who.int/docs/default-source/ coronaviruse/situation-reports/20200219-sitrep-30-covid-19. pdf?sfvrsn=-3346b04f_2

9. Zou L, Ruan F, Huang M, et al. SARS-CoV-2 viral load in upper respiratory specimens of infected patients. $\mathrm{N}$ Engl $\mathrm{J}$ Med 2020;382(12):1177-9.

10. Dikmen Uğraş A, Kına HM, Özkan S, et al. COVID-19 Epidemiyolojisi: Pandemiden ne öğrendik? J Biotechnol and Strategic Health Re 2020;1(Özel Sayı):29-36.

11. Khan MM, Parab SR. Simple economical solution for personal protection equipment (face mask/shield) for health care staff during COVID 19. Indian J Otolaryngol Head Neck Surg 2020;1:1-5.

12. Centers for Disease Control and Prevention [Internet]. Coronavirus disease 2019 (COVID-19) how to protect yourself - [cited 2020 Mar 18]. Available from: https://www. cdc.gov/coronavirus/2019-ncov/prepare/prevention.html

13. T.C. Sağlık Bakanlığı [Internet]. Yeni Koronovirüs hastalığı.[cited 2020 May 10]. Available from: https://covid19bilgi. saglik.gov.tr/tr/afis

14. Lin YH, Liu CH, Chiu YC. Google searches for the keywords of "wash hands" predict the speed of national spread of COVID-19 outbreak among 21 countries. BBI 2020;87:30-2.

15. Gökçay G, Keskindemirci G. Anne Sütü ve COVID-19. İst Tıp Fak Derg 2020;50-5.

16. World Health Organization [Internet]. Advice on the use of masks in the community, during home care and in healthcare settings in the context of the novel coronavirus (COVID-19) outbreak - [cited 2020 May 10]. Available from: https://www. who.int/publications-detail/advice-on-the-use-of-masksin-the-communityduring-home-care-and-in-healthcaresettings-in-the-context-of-the-novel-coronavirus-(2019ncov)-outbreak

17. Kutlu R. What we have learned about the new coronavirus pandemic, current diagnostic and therapeutic approaches and the situation in Turkey? TJFMPC 2020;14(2):329-44.

18. Alıcılar HE, Çöl M. Yeni koronavirüs salgını: Korunmada etkili yaklaşımlar [Internet]. Ankara Üniversitesi Tıp Fakültesi Halk Sağlığı Anabilim Dalı;2020 [cited 2020 May 10]. Available from: https://korona.hasuder.org.tr/wp-content/uploads/Yeni-
Koronavir\%C3\%BCs-Salg\%C4\%B1n\%C4\%B1-KorunmadaEtkili-Yakla\%C5\%9F\%C4\%B1mlar.pdf

19. T.C. Sağlık Bakanlığı [Internet]. COVID-19 (SARS-CoV2 Enfeksiyonu) Rehberi 14 Nisan 2020 - [cited 2020 May 10]. Available from: https://covid19bilgi.saglik.gov.tr/depo/ rehberler/COVID-19_Rehberi.pdf

20. World Health Organization [Internet]. Coronavirus disease (COVID-19) advice for the public - [cited 2020 May 19]. Available from: https://www.who.int/emergencies/diseases/ novel-coronavirus-2019/advice-for-public

21. Halk Sağlığı Genel Müdürlüğü [Internet]. COVID-19 Halka Yönelik Sıkça Sorulan Sorular - [cited 2020 May 19]. Available from: https://hsgm.saglik.gov.tr/tr/covid19-sss/ covid-19-halka-yonelik.html

22. Royal College of Paediatrics and Child Health [Internet]. COVID-19- guidance for paediatric services. $\mathrm{RCPCH}$. London - [cited 2020 May 19]. Available from: https://www. rcpch.ac.uk/sites/default/files/generated-pdf/ document/ COVID-19-guidance-for-paediatric-services.pdf

23. World Health Organization [Internet]. Q\&A on COVID-19, pregnancy, childbirth and breastfeeding.World Health Organization. Geneva - [cited 2020 May 19]. Available from: https://www.who.int/news-room/q-a-detail/ q-a-on-covid-19pregnancy-childbirth-and-breastfeeding

24. Academy of Breastfeeding Medicine [Internet]. Academy of breastfeeding medicine statement on Coronavirus 2019 (COVID-19) - [cited 2020 May 19]. Available from: https:// www.bfmed.org/abm-statementcoronavirus

25. Center for Disease Control [Internet]. Coronavirus disease 2019 (COVID-19)Are Pregnant, Breastfeeding, or Caring for Young Children - [cited 2020 May 19]. Available from: https:// www.cdc.gov/ coronavirus/2019-ncov/prepare/pregnancybreastfeeding. 